JAMES Y. SIMMS, JR.

\title{
The Crisis in Russian Agriculture at the End of the Nineteenth Century: A Different View
}

One of the most important and most generally espoused interpretations in Russian history is the existence of a crisis in Russian agriculture toward the close of the nineteenth century. A discussion of this crisis or agrarian problem is found in contemporary, in Soviet, and in the Western scholarly works. ${ }^{1}$ Statements such as "the economic condition of the peasantry kept deteriorating."2 or "famine conditions, epidemics, increased mortality, decrease in the number of livestock, . . . this is the spectacle of the growing destitution of a faminestricken Russian village,"3 are commonplace. In fact, "to numerous observers of Russian rural conditions, the growing destitution of the village seemed so evident that it required no special demonstration." 4 The purpose of this paper is to

1. Over two dozen citations could be provided to prove the point. See, for example, the following contemporary sources: Paul Miliukov, Russia and Its Crisis (New York: Collier Books, 1962), p. 316; S. Iuzhakov, "Voprosy ekonomicheskago razvitiia v Rossii," Russkoe bogatstvo, 1893, no. 12, pp. 203-4; N. A. Karyshev, "Letnie vpechatleniia: Padenie khlebnykh tsen," Russkoe bogatstvo, 1894, no. 8, p. 53 ; "Sel'sko-khoziaistvennyi krizis i prodovol'stvennaia nuzhda v Pskovskoi gubernii," Russkoe bogatstvo, 1896, no. 2, pp. 188-89; and A. I. Chuprov and A. S. Posnikov, eds., Vliianie urozhaev $i$ khlebnykh tsen na nekotoriia storony russkago narodnago khoziaistva (St. Petersburg, 1897), p. xli. Soviet sources include: P. A. Khromov, Ekonomika Rossii perioda promyshlennogo kapitalizma (Moscow, 1963), pp. 206-7, 210 ; N. A. Egiazarova, Agrarnyi krizis kontsa XIX veka v Rossii (Moscow, 1959), pp. 3-10, 83-84, 138-52; and Peter L. Lyashchenko, History of the National Economy of Russia, trans. L. M. Herman (New York: MacMillan, 1949), pp. 439 ff. Western sources include: Wayne S. Vucinich, ed., The Peasant in Nineteenth Century Russia (Stanford: Stanford University Press, 1968), p. xvi; Francis M. Watters, "The Peasant and the Village Commune," in The Peasant in Nineteenth Century Russia, ed. Wayne S. Vucinich (Stanford: Stanford University Press, 1968), pp. 133 and 152; Theodore H. Von Laue, "The State and the Economy," in The Transformation of Russian Society, ed. Cyril Black (Cambridge, Mass.: Harvard University Press, 1960), pp. 298 and 301; Hugh Seton-Watson, The Russian Empire 1801-1917 (Oxford: Clarendon Press, 1967), pp. 514-17; Sidney Harcave, The Russian Revolution of 1905 (London: Collier Books, 1970), pp. 19-20; and Richard Robbins, Famine in Russia 1891-1892 (New York: Columbia University Press, 1975), pp. 3-10.

2. Alexander Gerschenkron, "Agrarian Policies and Industrialization: Russia 1861-1917," in Cambridge Economic History of Europe, vol. 4, part 2, ed. H. J. Habakkuk and N. Postan (Cambridge: Cambridge University Press, 1965), p. 776.

3. Lazar Volin, "The Russian Peasant: From Emancipation to Kolkhoz," in The Transformation of Russian Society, ed. Cyril Black (Cambridge, Mass.: Harvard University Press, 1960), p. 298.

4. Lazar Volin, A Century of Russian Agriculture: From Alexander II to Khrushchev (Cambridge, Mass. : Harvard University Press, 1970), pp. 57-58. 
examine the indexes used to support the crisis interpretation, and to show that this interpretation is not only arguable, but probably fallacious. ${ }^{5}$

When scholars and intellectuals speak of a crisis in Russian agriculture, they generally mean that the rural economy and thus the overwhelming majority of the rural population had declined economically to a point verging upon destitution. ${ }^{6}$ It is extremely important to understand that scholars and contemporaries have tended to discuss the Russian peasant collectively. ${ }^{7}$ The crisis always encompasses the exhaustion of the paying powers of the population, or the universal poverty of the peasantry. ${ }^{8}$ The following quotations are illustrative:

In the last resort it was the peasantry who had to pay, far beyond their resources, for the development of industry. This was a sequel to the government's fiscal policy of indirect taxation and also to the high prices of imported goods following the imposition of the protectionist tariff. Industry, therefore, far from bringing benefit to the mass of Russians, actively contributed to their impoverishment. ${ }^{9}$

The chief sufferer from this neglect was, of course, the peasant: the landlords, with their superior education and financial resources, either did not need outside assistance or could more easily obtain and pay for it than the poverty-stricken peasants. ${ }^{10}$

The implication is clear: it was the mass of the population, or the vast majority of the peasants, who had become impoverished and destitute by the turn of the century. This is a basic component in the crisis hypothesis.

The question is, of course, did a majority of the peasants become impoverished? The important consideration here is not whether there were poor peasants, but whether they constituted a majority of the peasantry. Thus, to refute the crisis interpretation, one must examine in detail the two most important indexes of peasant well-being: (1) tax receipts or the burden of taxation, and (2) the overall standard of living of the peasant.

5. For those interested in a more detailed discussion of this topic, see chapter 5 of James Y. Simms, Jr., "The Impact of the Russian Famine of 1891-92: A New Perspective" (Ph.D. diss., University of Michigan, 1976).

6. See, for example, Volin, A Century of Russian Agriculture, p. 59; Watters, "The Peasant," pp. 152 and 157; Harcave, Russian Revolution of 1905, pp. 19 and 20.

7. See, for example, George Pavlovsky, Agricultural Russia on the Eve of the Revolution (London: George Routledge and Sons, 1930), pp. 27, 84, 251; and Geroid T. Robinson, Rural Russia under the Old Regime (New York: MacMillan, 1967), pp. 94, 97, 99, 103, 110-11,

8. Theodore H. Von Laue, "The High Cost and the Gamble of the Witte System," in Readings in Russian History, vol. 2, ed. Sidney Harcave (New York: Thomas Y. Crowell, 1968), p. 72.

9. Lionel Kochan, Russia in Revolution 1890-1918 (New York: American Library, 1966), pp. 3-4.

10. Volin, A Century of Russian Agriculture, p. 67. See also Leopold Haimson, The Russian Marxists and the Origins of Bolshevism (Cambridge, Mass.: Harvard University Press, 1955), pp. 49-50; Donald W. Treadgold, Lenin and His Rivals (New York: Frederick A. Praeger, 1955), p. 12; Solomon M. Schwarz, "Populism and Early Russian Marxism on Ways of Economic Development of Russia," in Continuity and Change in Russian and Soviet Thought, ed. E. J. Simmons (Cambridge, Mass.: Harvard University Press, 1955), p. 43; and Von Laue, "High Cost and the Gamble of the Witte System," p. 72, who make similar statements. 
Any discussion of Russian agriculture, and especially income distribution, should be prefaced with the statement that sufficient data do not exist from which one can make indisputable judgments. One can only make inferences. Geroid T. Robinson emphasized this point by stating that:

when all was said and done, the means did not exist (nor do they now exist) for determining, year by year, during the decades which preceded and followed the Emancipation, the total "real" income of the peasantry; nor is it possible even now to measure cumulatively all the changes in their economic situation. There are no all-inclusive data; the best that can be done is to select certain measurable factors, which appear to focus and reflect the general condition. ${ }^{11}$

Proponents of the agricultural crisis hypothesis claim that fiscal policies of the state, especially those of Vyshnegradskii and Witte, brought about the economic ruin of the peasantry. Intellectuals and scholars from the 1870 s to the present have stressed the role of taxation as a critical factor in the development of the crisis, arguing that the emancipation did not provide the peasant with sufficient land, required redemption payments in excess of the value of the land, and retained the mir and the age-old practice of joint responsibility for taxes. In addition to burdensome redemption payments, the peasants were also faced with zemstvo, village, and indirect taxes. ${ }^{12}$ (It should be noted that indirect taxes became far more important as a source of tax revenue than direct taxes in the last two decades of the century-over 80 percent of tax revenue came from indirect taxes by $1900 .{ }^{13}$ ) There seems to be universal agreement that high taxation depressed the income and standard of living of the peasant. ${ }^{14}$ At least one scholar goes so far as to state that the tsarist government "extorted" money from the population in the collection of taxes. ${ }^{15}$ It was, supposedly, the peasant sector, and not any other sector of the economy, that was forced to bear the cost of the government's programs. Thus, redemption payments in conjunction with high taxes created a burden that was a basic cause of the decline of the rural economy. ${ }^{16}$ Witte had supposedly taxed the peasant to exhaustion. ${ }^{17}$ The peasant class was reduced to abject misery. ${ }^{18}$

11. Robinson, Rural Russia under the Old Regime, p. 110. See also F. A. Shcherbina, "Krest'ianskie biudzhety i zavisimost' ikh ot urozhaev $i$ tsen na khleba," in Vliianie urozhaev i khlebnykh tsen na nekotoriia storony russkago narodnago khoziaistva, ed. A. I. Chuprov and A. S. Posnikov, vol. 2 (St. Petersburg, 1897), pp. 3 and 75.

12. See, for example, Robinson, Rural Russia under the Old Regime, pp. 94-117; and Lyashchenko, History of the National Economy of Russia, pp. 439-75. For a contemporary view, see L. Slonimskii, "Neurozhai i narodnoe bedstvie," Vestnik Evropy, 3 (May 1892): 345-64; and Karyshev, "Letnie vpechatleniia," pp. 43-71.

13. Von Laue, "High Cost and the Gamble of the Witte System," p. 70.

14. Volin, A Century of Russian Agriculture, p. 54; Seton-Watson, The Russian Empire, p. 510 .

15. Lyashchenko, History of the National Economy of Russia, p. 534.

16. Vucinich, The Peasant in Nineteenth Century Russia, pp, xvi-xvii.

17. Von Laue, "High Cost and the Gamble of the Witte System," p. 75 ; Kochan, Russia in Revolution, p. 16.

18. Watters, "The Peasant," p. 155. 
Fiscal policy of the state was considered the critical factor in the economic decline of the peasant for a number of reasons. First, taxes consumed a large share of peasant income and contributed nothing in exchange $;{ }^{19}$ second, the peasant was forced to sell all of his produce above subsistence; and, third, pressure was put upon him to extend the total area of farmland. Government policy thus resulted in higher rents because of increased competition for land, prices fell because of the flooded market, and the peasant, through his backward agricultural techniques, exhausted the soil-all of this a consequence of the peasant's attempt to meet his own and the state's fiscal needs. ${ }^{20}$

Numerous studies, emphasizing mainly the arrears in the redemption payments as proof of the inability of the peasant to meet his obligations, have supported the claim that the peasant's tax paying capacity was exhausted. In the twenty-year period from 1861 to 1881 , redemption arrears had gradually increased, but from 1881 to 1901 they rose rapidly. ${ }^{21}$ In 1880, peasant arrears in redemption payments amounted to 27 percent of the annual assessment. By 1896-1900, redemption arrears amounted to 119 percent of the annual assessment; this despite the reductions, deferments, and cancellations of debt that occurred in 1881, 1884, 1896, and 1899..22 This growth in redemption payment arrears is considered by students of the agricultural crisis-both modern and contemporary-as prima facie evidence of the distress throughout the Russian countryside. ${ }^{23}$ Proponents of the crisis theory apparently believe that redemption arrears measured the inability of the peasant to pay his taxes. ${ }^{24}$ They argue that if the peasant had had the money, he would have paid his taxes. Is this necessarily so?

Geroid T. Robinson, considered to be the leading authority on tsarist agriculture in this period, offers a hypothesis (and only a hypothesis) on why the arrears in the redemption payment demonstrates an inability to pay. Because this is a critical issue in both the standard theories concerning the crisis and the revisionist interpretation presented here, Robinson must be quoted at length:

in the search for an economic index, one may reconsider the question of dues and taxes. The peasant's obligations to the public treasury were a contributory cause of his distress, but the statistics as to the amount of these obligations are worthless, by themselves, as an index of the peasant's situation, for the reason that their total sum and all their fluctuations might

19. Volin, A Century of Russian Agriculture, p. 62.

20. This basic interpretation can be found in virtually every survey text of Russian history or monograph concerning Russian agriculture, for example, Florinsky, Robinson, Lyashchenko, and Volin. A similar view was also prevalent among the contemporaries, for example, Slonimskii, Karyshev, Plekhanov, Nikolai-on, Skvortsov, and even George Kennan.

21. Donald M. Wallace, Russia (New York: Cassell, 1912), pp. 535-36.

22. Robinson, Rural Russia under the Old Regime, pp. 95-96.

23. "Vnutrennee obozrenie," Vestnik Evropy, 3 (May 1892): 372-73; G. A. Fal'bork, "Glavnyia mery bor'by $\mathrm{s}$ golodom, kak neobkhodimym posledstviem neurozhaia $u$ nas $v$ Rossii," Trudy imperatorskago vol'nago ckonomicheskago obshchestva, November-December 1892, p. 253; Theodore H. Von Laue, Scrgei Witte and the Industrialization of Russia (New York: Columbia University Press, 1963), p. 170; Wallace, Russia, p. 535; Robinson, Rural Russia under the Old Regime, pp. 110-11; Volin, A Century of Russian Agriculture, p. 51; and Miliukov, Russia and Its Crisis, p. 373.

24. Robinson, Rural Russia under the Old Regime, p. 110. See also Miliukov, Russia and Its Crisis, p. 325. 
conceivably have been compensated by other economic factors. On the other hand, the data regarding the arrears in these public payments are altogether of a different order. What then is the significance of these arrears; is the default sometimes nothing more than an indication of unwillingness to pay? The answer may be found through even the most casual inquiry into the methods of collection. The seizure of property was not the only possible procedure when the payments were not met; the peasant and his family might be put to forced labor, and sometimes the whip was employed, even against an entire village, as an attempt to "beat out" the tax. An army of collectors heaved and strained at the task, . . . and the methods of collection being what they were, non-payment may be considered as usually indicative of a sheer inability to pay. The arrears therefore present perhaps the best of all indices of the peasants' economic situation, and their considerable total, their wide territorial distribution, and the fact of their continued accumulation would seem to indicate a widespread and increasing distress in the village $(s) .{ }^{25}$ [Emphases added.]

This statement makes perfectly clear the importance of tax arrears to the picture of rural distress that has existed in Russian agricultural historiography since the Valuev Commission of the 1870 s. The most important substantiation of the existence of the agricultural crisis rests on the assumption that the Russian peasant, if he had anything at all, would have paid his tax obligations out of fear of the tax collector. If he faced floggings, exile, and the sale of his property, it must be because he was already destitute. ${ }^{26}$ It will be shown, however, that this "proof" of peasant distress is open to question. An examination of available evidence indicates that the "army of tax collectors" did not extract from the peasantry all available money for the payment of taxes, which in turn makes possible a reinterpretation of the significance of the increasing tax arrears.

With the advent of Vyshnegradskii as minister of finance and the increased emphasis on tax collections, the growth in tax receipts was notable. There was, for example, a marked increase in the redemption payments in 1887, the first full year of Vyshnegradskii's tenure, as compared to 1886. A similar significant increase took place in the receipts of indirect taxes. ${ }^{27} \mathrm{It}$ has been assumed that the increase in receipts and the promptness of payment were a result of ruthless and more efficient methods of tax collection. But, on the contrary, the fact of excellent harvests in these years and the obvious relationship between good harvests and ability to pay renders the above assumption somewhat otiose.

25. Robinson, Rural Russia under the Old Regime, pp. 110-11.

26. The image of such harsh methods of tax collection is quite common in the literature on the subject. The following is a brief sample: Lyashchenko, History of the National Economy of Russia, p. 513; Volin, A Century of Russian Agriculture, p. 52; Gerschenkron, "Agrarian Policies and Industrialization," p. 786; New York Times, July 13, 1891, p. 6; G. V. Plekhanov, "Vserossiiskoe razorenie," Sotsial Demokrat, 4 (1892), pp. 85 and 93; Free Russia, 2 (August 1891), p. 14; Slonimskii, "Neurozhai," pp. 354-55; Fal'bork, "Glavnyia mery bor'by s golodom," p. 251 ; Lev N. Tolstoi, Golod ili ne golod? (Essex, England: Vladimir Chertkov, 1898), p. 15; and Nikolai-on, Ocherki nashego poreformennago khoziaistva (St. Petersburg, 1893), p. 257.

27. See P. A. Khromov, Ekonomicheskoe rasvitie Rossii v $X I X-X X$ vekakh (MoscowLeningrad, 1950), pp. 489-99, which shows an increase of 40 million rubles in redemption payments and 12 million rubles in indirect tax receipts on consumer goods. 
Table 1. Imperial Receipts from 1886-1899 (thousands of rubles)

\begin{tabular}{lccc}
\hline Year & Liquor Receipts & Indirect Taxes & Redemption Receipts \\
\hline 1886 & 236,977 & 35,262 & 48,788 \\
1887 & 257,624 & 47,255 & 88,958 \\
1888 & 265,125 & 54,520 & 92,270 \\
1889 & 274,920 & 59,913 & 91,747 \\
1890 & 268,381 & 64,685 & 88,232 \\
1891 & 247,442 & 64,290 & 69,049 \\
1892 & 269,046 & 75,274 & 77,088 \\
1893 & 260,834 & 85,104 & 98,994 \\
1894 & 297,386 & 100,248 & 92,819 \\
1895 & 298,215 & 109,519 & 101,297 \\
1896 & 294,299 & 105,988 & 96,946 \\
1897 & 280,129 & 120,664 & 88,519 \\
1898 & 289,573 & 126,398 & 86,152 \\
1899 & 310,297 & 139,424 & 95,496 \\
\hline
\end{tabular}

Source: P. A. Khromov, Ekonomicheskoe razvitie Rossii $v$ XIX-XX vekakh (MoscowLeningrad, 1950), pp. 498-99, 502-3.

Furthermore, the ability of the peasants to pay taxes, especially indirect taxes, might actually indicate economic well-being and not a drastic economic decline. ${ }^{28}$

Tax arrears-that is, an ever increasing peasant debt-does not by itself indicate economic decline, as Robinson acknowledged. In the short run, a mounting debt does not demonstrate a lower standard of living for it represents a source, not a use of funds by peasants; in the long run, it is not a great factor because the government eventually cancelled all redemption payments. In one sense, the real loser because of the ever growing tax arrears was not the peasant but the state, even though the government was probably better off financially than at any time in the nineteenth century. It is well known that the government "extorted" sufficient funds from the countryside through indirect taxes to meet its fiscal requirements. In addition, the fiscal policy of the ministers of finance helped to pecuniarize the rural sector-the charge made by the Populists-and thereby forced the peasants to expand the cereal growing area, which increased production and exports, and in turn provided Russia a favorable balance of trade.

An examination of the actual tax receipts of the period (table 1) sheds considerable light on the question of peasant economic welfare. From 1887 to 1899, redemption receipts remained relatively stable, with the obvious exception of 1891 and 1892. Excluding 1891-92, the average collection of redemption dues was approximately 93 million rubles; using that figure as a comparison base, one observes relatively minimal fluctuations from year to year. Or if one averages redemption payments for the period $1887-90$, the average yearly collection is approximately 90 million rubles, whereas the average annual collection for 189699 is approximately 91 million rubles, further underscoring the relative stability of the collection of redemption dues. Moreover, by classifying redemption payments according to the social status of the payee (table 2), one finds that the main fluctuation in payments occurred for the payments of the former state

28. Olga Crisp, "Russian Financial Policy and the Gold Standard at the End of the Nineteenth Century," Economic History Review', 6, no. 2 (December 1953): 165. 
Table 2. Payment in Redemption of Land (thousands of rubles)

\begin{tabular}{ccc}
\hline Year & $\begin{array}{c}\text { From Former Serfs } \\
\text { of Private Owners }\end{array}$ & $\begin{array}{c}\text { From Former Peasants } \\
\text { of the State }\end{array}$ \\
\hline 1887 & 43,285 & 45,672 \\
1888 & 43,052 & 49,217 \\
1890 & 42,414 & 49,332 \\
1891 & 40,967 & 47,265 \\
1892 & 34,850 & 34,197 \\
1893 & 35,763 & 39,223 \\
1894 & 42,802 & 53,128 \\
1895 & 40,100 & 49,642 \\
1896 & 42,123 & 55,845 \\
1897 & 40,625 & 53,096 \\
1898 & 37,543 & 47,952 \\
& 38,018 & 46,303 \\
\hline
\end{tabular}

Source: The Russian Journal of Financial Statistics (St. Petersburg, 1899), pp. 222-23.

peasants, the more prosperous element among the peasants. Meanwhile, receipts from indirect taxes steadily increased and almost tripled from 1886 to 1899 , and liquor revenue increased approximately 30 percent.

The tax data in table 1 clearly show that sufficient income was available in the countryside to permit an absolute increase in total tax revenue for the state. If Robinson's hypothesis is correct-that the peasant was under tremendous and ruthless tax pressure from the Ministry of Finance via the tax collectorshould it not have been the receipts from redemption payments, the fixed taxes "forcibly" collected, that showed a marked increase, rather than the indirect tax receipts? Taxes were collected in the fall after the harvest, ${ }^{29}$ and any money available in the village, according to Robinson's theory, would have been extracted for the payment of the arrears in direct taxes. The evidence shows, however, that income was retained in the village-held back from the tax collector-and spent to purchase consumer goods. Otherwise, how can one explain the marked increase in indirect tax receipts?

A proponent of the crisis theory might argue at this point that the critique of the arrears hypothesis ignores the problem of income distribution. It could well be that wealthy peasants not only were paying their redemption debts but also had money left over to contribute to the rise in indirect tax income. The poverty-stricken peasants, on the other hand, had neither money for redemption payments nor did they contribute to indirect taxes by purchasing consumer items. This reply, however, overlooks the joint responsibility of the commune for redemption payments. Under this law, the wealthier peasants would have had to make up the arrears of the poorer peasants. ${ }^{30}$ It also overlooks the evidence adduced by Lenin, which shows that even the poorest category of the peasantry was spending a considerable amount of income on the purchase of personal items. ${ }^{31}$

29. Volin, A Century of Russian Agriculture, pp. 52-53; Von Laue, Sergei Witte, pp. 26-27; and Chuprov and Posnikov, Vliianie uroshaev $i$ khlebnykh tsen, pp. xviii-xix.

30. See Volin, A Century of Russian Agriculture, p. 52, for a discussion of the joint responsibility for the payment of taxes.

31. Vladimir Lenin, The Development of Capitalism in Russia, in Collected Works, vol. 3 (Moscow: Foreign Language Publishing House, 1960), pp. 164-65. 
Additional evidence to substantiate the view that it was the peasantry at large that was doing the consuming can be found, ironically, within the very arguments used to support the crisis theory:

And while Witte continued to argue that they [indirect taxes] were paid only by those who could afford them, his critics showed convincingly that many taxed items constituted part of the peasants' household economy, such as tea, vodka, matches, and kerosene.

For the consumer the result was a slight rise in the price of vodka, which fell as another burden especially upon the peasants who would not dispense with liquor. ${ }^{32}$

And, in order to support his pet industries, Witte taxed the population to exhaustion. ... . He thus sapped the initiative of the Russian peasants, kept them in their primitive condition, ruined their health, denuded their forests. .. . Such a system could only end in the utter ruin of Russia. ${ }^{33}$.

Or:

If any further evidence is needed of the heavy fiscal burden imposed on the Russian peasantry by redemption payments and taxes. . . .

Since excise taxes, in order to produce revenue, must be imposed on articles of mass consumption, the peasant population naturally was bound to bear the brunt of indirect taxation. ${ }^{34}$

Based on the evidence presented above, those who argue that the burden of taxation-reflected in the arrears-was borne by the mass of the peasantry

32. Von Laue, "High Cost and the Gamble of the Witte System," p. 70.

33. Ibid., pp. 75-76. Kochan states: "In the last resort it was the peasantry who had to pay, far beyond the resources, for the development of industry. This was the sequel to the government's fiscal policy of indirect taxation and also to the high prices of imported goods following the imposition of the protectionist tariff. Industry, therefore, far from bringing benefit to the mass of Russians, actively contributed to their impoverishment" (Kochan, Russia in Revolution, pp. 3-4). "But during this transition period, he [Witte] had to acknowledge that taxes and import duties reduced a standard of living that was already at a bare subsistence level, that taxes were paid 'not out of excess but out of current needs. . . . The Vitte system was tantamount to squeezing the peasantry tighter and tighter for the sake of a problematic future benefit" (Kochan, Russia in Revolution, p. 16). Robinson states that "the proceeds of indirect taxation were drawn chiefly from levies on such things as vodka, sugar, tobacco, kerosene, and matches and from import duties on tea, cotton, iron and the like. In other words, the burden rested chiefly upon articles of general consumption and was therefore borne in considerable part by the peasant mass" (Robinson, Rural Russia under the Old Regime, p. 96). Vucinich states that "another shortcoming was the heavy redemption price the peasant was forced to pay for his land. This, coupled with high taxes, created a fiscal burden that was a prime cause of increasing rural poverty. . . . the peasant sector, forced to pay most of the cost of his program was ignored" (Vucinich, The Peasant in Nineteenth Century Russia, pp. xvi-xvii).

34. Volin, A Century of Russian Agriculture, pp. 52-53. See also George F. Kennan, "A Theory of Circumstantial Causation," in The Russian Revolution, ed. Virgil D. Medlin (Hinsdale, Ill.: The Dryden Press, 1974), p. 30. Contemporaries also believed that the peasantry at large bore the brunt of taxation. See Miliukov, Russia and Its Crisis, p. 325; Ivan Sergeevskii, Golod v Rossii (Geneva: Society of Old Populists, 1892), p. 32; and Nikolai-on, Ocherki, pp. 258-59. 
and brought Russian agriculture to ruin must cope with one very awkward fact. If the peasants were the primary source of indirect tax income, then they must have been the major consumer of the goods taxed, that is, sugar, matches, and so forth. Therefore, since they could purchase nonagricultural goods, one can hardly depict the rural sector as ravaged by a ruthless tax system.

Advocates of the "crisis" theory cannot avoid this dilemma by arguing that the peasants did not pay the indirect taxes, for in that case there could not have been an agricultural crisis. One can no longer argue that monetary demands ruined peasant husbandry by forcing the peasant to exhaust his soil, rent land, and flood the market with grain for export, in order to pay his taxes. Either the peasantry paid the taxes and thus obviously was a consumer of nonagricultural goods, or he did not pay the taxes-the indirect tax receipts being derived from urban centers and wealthy peasants-and therefore the mass of the peasantry could not have been ruthlessly exploited by the state. It will be demonstrated below that, in fact, the former option is the more likely.

Peasant land redemption arrears grew not because of an inability to pay, but because of an unwillingness to pay. Apparently the peasantry acknowledged the demands of the tax collector only up to a point, and beyond that point would pay no more in redemption taxes. It violates one's common sense to believe that tsarist officials literally flogged and extorted tax payments from all the peasants. Without question, such things did take place, but hardly against all one hundred million people. One might note that the threat of extortion and high taxation also failed to bring the peasants into line in the later era of "War Communism." Lenin was forced to make concessions because peasants were not bringing their grain to the cities to sell, and hence the introduction of NEP. Had flogging been enough, Stalin might not have had to wage war on the peasantry (from 1929 to 1934 ) in order to subordinate the peasants to the state..$^{35}$

The government's fiscal program in the 1880 s and 1890 s had as its goal the industrialization and modernization of Russia. To accomplish this task the state needed income-derived either from direct or indirect taxes. The growth in the relative importance of indirect taxes is probably attributable to the fact that they were easier to collect. Because the government obtained the requisite funds without a great deal of commotion, one really cannot see the need for the minister of finance, that is, the tax collector, to be as stringent in the collection of taxes as has often been alleged. As Witte is supposed to have stated to the tsar in 1893: "Indirect taxes have essential advantages over direct taxes, because their collection is much easier, does not demand any kind of forceful measures, which are always severe and often disadvantageous for the taxpayers, and the payment of indirect taxes is performed, according to the consumption of products assessed, with small tax payments, and at such time when the payer has the means for buying these products, and consequently for the payment of the taxes." 86

35. There is evidence which shows that the peasants did not passively submit to the tax collector. See A. V. Shapkarin, ed., Krest'ianskoe dvizhenie v Rossii v 1890-1900 gg. (Moscow, 1959), pp. 114-21.

36. Cited by A. P. Pogrebinskii, Ocherki istorii finansov dorevoliutsionnoi Rossii (XIX$X X v v$ ) (Moscow, 1954), p. 99. 
Proponents of the "crisis" theory have either ignored or overlooked evidence which suggests that the tax burden was not obviously oppressive. In 1930, George Pavlovsky, author of Agricultural Russia on the Eve of the Revolution, stated quite emphatically that the redemption payments were not a heavy burden on the peasants after the reduction made in the size of those payments in $1881 .{ }^{37}$ A scholarly observer of the agricultural problem, A. I. Skvortsov, stated in 1894 that the burden of taxes varied considerably from peasant to peasant, even among former landlord serfs. In addition, the huge number of former state peasants were not burdened with taxes at all. It was also the non-black earth districts which were most heavily taxed and yet seemed the most prosperous. ${ }^{38}$ Even the arch advocate of the theory of ruination of the rural sector, Nikolai-on, acknowledged in 1893 that taxes were not high enough to explain the deplorable state of the peasant's life. ${ }^{39}$

The use of tax data and redemption arrears as evidence of a Russian agricultural crisis at the turn of the nineteenth century has been found wanting. There remains the task of ascertaining a measure of the general standard of living of the Russian peasant to determine whether in fact the status of the peasant was deteriorating. Ironically, the overall increase in indirect tax receipts may serve as an index of growing prosperity, not poverty.

As indicated above, indirect tax receipts supposedly were derived from the people at large; the peasant constituted the mass consumer in Russia. Thus, the increase of tax receipts, placed on items of general and daily consumption such as alcohol, kerosene, tobacco, cotton, and sugar, "may serve as an adequately accurate index of fluctuations in the comfort and well-being of the people." 40 Table 1 shows that the volume of indirect tax receipts grew tremendously. Because indirect taxes were a function of units purchased and not related to the price of the goods, it follows that an increase in tax receipts would reflect an increase in units consumed. ${ }^{41}$ It can be argued, of course, that the increase in tax receipts only reflected a proportionate increase in the rate of taxation. It is well known that the rate of indirect taxes was raised considerably by the minister of finance in the last two decades of the nineteenth century. Scholars argue that the indirect tax rate more than doubled-rose by 108 percent -between 1881 and $1901 .^{42}$ But receipts from indirect taxes, excluding alcohol receipts, rose by 850 percent from 1881 to 1899 , which clearly means consumption was growing at a faster pace than the increase in the tax rate. ${ }^{43}$ Similarly, Miliukov states that from 1893 to 1902 the tax burden had risen 49 percent, ${ }^{44}$

37. Pavlovsky, Agricultural Russia, p. 78.

38. A. I. Skvortsov, Ekonomicheskie etiudy (St. Petersburg, 1894), pp. 71-72.

39. Nikolai-on, Ocherki, p. 257; and Arthur P. Mendel, Dilemmas of Progress in Tsarist

Russia (Cambridge, Mass.: Harvard University Press, 1961), p. 57.

40. Chuprov and Posnikov, Vliianie uroshaev i khlebnykh tsen, p. lii.

41. See Lyashchenko, History of the National Economy of Russia, p. 510; and Pogrebinskii, Ocherki istorii finansov, p. 191.

42. Von Laue, "High Cost and the Gamble of the Witte System," p. 70; and Volin, A Century of Russian Agriculture, p. 53.

43. Khromov, Ekonomicheskoe raszitie Rossii, pp. 498-99, 502-3.

44. Miliukov, Russia and Its Crisis, p. 322. 
but table 1 shows that by 1899 indirect tax receipts were already up approximately 64 percent.

The general rise in consumption-real income-throughout Russia, a question of serious academic debate since the $1890 \mathrm{~s}$, is important to the issue of a crisis in Russia. If real income and consumption were rising, then the hypothesis of a crisis based on the exhaustion of the Russian masses must be wrong.

Contemporaries, especially the critics of Witte's industrialization program, were almost eager in their desire to show that there was no noticeable improvement in real income-popular consumption-even during the great spurt of industrialization of the $1890 \mathrm{~s}^{45}$ Present-day advocates of declining real income include one of the most knowledgeable students of this period, Alexander Gerschenkron. Gerschenkron argues that consumption levels within Russia dropped in the last decade of the century, through the implementation of forced savings (inflation) and taxation. Thus, in his opinion, the Russian populace was called upon to make sacrifices during the transitional stage to an advanced industrial society. ${ }^{46}$

Paradoxical as it may seem, Lenin offered an opinion which would place him among the few who have said that the standard of living of the peasant was improving. He stated:

the peasants have begun to live a "cleaner" life (as regards clothing, housing, and so forth). That this undoubtedly progressive phenomenon must be placed to the credit of Russian capitalism and of nothing else is proved by the generally known fact ... that peasants of the industrial localities live a far "cleaner" life than the peasants engaged exclusively in agriculture and hardly touched by capitalism. Of course, that phenomenon is manifested primarily and most readily in the adoption of the purely outward, ostentatious aspect of "civilization," but only arrant reactionaries like Mr. V. V. are capable of bewailing it and seeing nothing in it but "decline." 47

45. Von Laue, "High Cost and the Gamble of the Witte System," p. 69; Von Laue, Sergei Witte, p. 211. See also Mendel, Dilcmmas of Progress, pp. 45 and 48 . The context in which the argument was presented suggests that both of these scholars accepted the contemporary view.

46. Alexander Gerschenkron, "The Problem of Economic Development in Russian Intellectual History of the Nineteenth Century," Contimity and Change in Russian and Soviet Thought, ed. E. J. Simmons (Cambridge, Mass.: Harvard University Press, 1955), pp. 14-15, 37. A parallel argument is made by many students of Soviet economic history, in that it is hypothesized that the rapid industrialization program of the 1930s was predicated on the exploitation of the agrarian sector, which thus made a net contribution to the industrialization of the Soviet Union. My findings suggest that the peasant sector did not disproportionately bear the brunt of industrialization in the 1890s. James R. Millar has drawn a similar conclusion for 1928-34 in Soviet Russia. See James R. Millar, "Soviet Rapid Development and the Agricultural Surplus Hypothesis," Soviet Studies, 22 (July 1970) : 77-93; and James R. Millar, "Mass Collectivization and the Contribution of Soviet Agriculture to the First FiveYear Plan: A Review Article," Slavic Revieze, 33, no. 4 (December 1974) : 750-66.

47. Vladimir Lenin, "On the So-called Market Question," in Collected Works, vol. 1 (Moscow: Foreign Language Publishing House, 1963), p. 107. 
A statistical study made by Raymond Goldsmith challenges the basic interpretation of the "crisis." He concludes that the average annual rate of growth of both the gross national product and gross national income increased absolutely from 1860 to 1913 , and especially from 1885 to $1913 .{ }^{48}$

The evidence, despite efforts to make it indicate the contrary, clearly shows that general consumption did increase in the last decade of the nineteenth century. The cotton industry of Russia, for example, rested on a mass domestic market and the consumption and production of cotton made rapid absolute gains in the period from 1880 to 1900 , and especially in the 1890 s. In that decade, per capita consumption rose by 56.5 percent and total consumption by 75 percent. Cotton production itself rose by approximately 100 percent. ${ }^{49}$

Witte himself claimed an increase in the consumption of cotton goods of 25 percent per capita from 1892 to 1900 . However, critics of his statistics went to considerable lengths to refute them. They argued that this was only a slight increase, and that it reflected simply a change from homespun goods to the purchase of manufactured goods, which represented no real improvement. One critic, Butmi, found that the actual consumption of raw cotton was down, and that if there was an increase in the consumption of cotton goods it denoted a decline in quality. ${ }^{50}$ But whatever the criticism, no hard evidence was presented to refute the basic proposition, that is, that the consumption of cotton per capita increased.

The government claimed that per capita sugar consumption had increased by 2.92 pounds during the decade of the nineties. ${ }^{51}$ The critics also found fault with these data. Von Laue argues that Butmi's findings showed an increase in per capita consumption of sugar of only 0.9 of a pound. ${ }^{52}$ In this regard, an examination of Butmi's figures shows an increase of 0.9 of a pound from 1894 and not from 1892: $1894-9.7$ pounds of sugar consumed per capita; 190010.6 pounds consumed per capita; thus an increase of 0.9 of a pound. ${ }^{53}$ If the 1892 figure is used, however, following N. O. Osipov, one obtains the following results: $1892-8.3$ pounds of sugar consumed per capita; ${ }^{54} 1900-10.6$ pounds consumed per capita. The figures now reveal an increase in sugar consumption of 2.3 pounds per capita. In either case, consumption of sugar per person in Russia was definitely increasing in the critical decade of the agricultural crisis.

48. Raymond W. Goldsmith, "The Economic Growth of Tsarist Russia 1860-1913," Economic Development and Cultural Change, 9 (April 1961): 412-13. See also Crisp, "Russian Financial Policy," p. 165, who feels that conditions might have been improving rather than declining within the agricultural sector.

49. Lyashchenko, History of the National Econony of Russia, p. 509; Khromov, Ekonomicheskoe razvitie Rossii, pp. 452-53, 460-61; and Von Laue, Sergei Witte, p. 268.

50. Von Laue, "High Cost and the Gamble of the Witte System," p. 69. See also George V. Butmi, Itogi finansovago khosiaistva s 1892 po 1903 (St. Petersburg, 1904), pp. 48-50.

51. Von Laue, "High Cost and the Gamble of the Witte System," p. 69; and Von Laue, Sergei Witte, p. 274.

52. Von Laue, "High Cost and the Gamble of the Witte System," p. 69.

53. Butmi, Itogi finansovago khoziaistva, pp. 50-51.

54. N. O. Osipov, "O nekotoroi zavisimosti mezhdu tsenoiu khleba i postupleniem aktsiznykh soborov za poslednee 10-letie," in Vliianie uroshaev $i$ khlebnykh tsen na nekotoriia storony russkago narodnago khosiaistva, ed. A. I. Chuprov and A. S. Posnikov (St. Petersburg, 1897), p. 377. 
The consumption of tea increased on such a scale that the government's data were not challenged. ${ }^{55}$ Per capita consumption of tea increased approximately 30 percent from 1890 to $1900 .{ }^{58}$ The consumption of matches also increased, at least from 1888 to 1894 , by approximately 10 percent. $^{.57}$

Finally, the state claimed an increase in consumption of illuminating oils (kerosene) of approximately 28 percent from 1892 to $1900 .{ }^{58} \mathrm{Butmi}$, however, using 1893 and 1899 as his measuring points, found a 4.9 percent per capita decline in consumption of kerosene ${ }^{59} \mathrm{He}$ also used a per capita consumption figure for 1893 of 12.3 pounds which was considerably higher than the 10.5 pound figure for 1892 and the 10.8 figure cited for 1893 by Osipov. ${ }^{80}$ Butmi claimed that the source for his figures, the official collector of indirect taxes, did not have the data for 1900, therefore the figure for 1899-11.7 pounds-was used. One wonders, however, why he did not use the figures for 1892 instead of 1893; he had them for other consumer items. Nevertheless, the preponderance of evidence suggests that per capita consumption of kerosene did increase somewhat, as reported by the state. ${ }^{61}$

There was, however, one major consumer item which did show a decline in per capita consumption from 1886 to 1900 . The consumption of alcohol dropped slightly, but this may have been caused by numerous factors, such as governmental interference, and does not necessarily reflect declining economic conditions of the peasantry. ${ }^{62}$ Tax receipts from alcohol did continue to increase throughout the period, and governmental revenue per capita from the sale of alcohol was virtually the same in 1897 as it was in $1867 . .^{63}$ The data presented here lead to the conclusion that, in terms of the domestic mass consumption market of cotton goods, sugar, tea, kerosene, and matches, not only tax receipts but also consumption per capita was increasing in the last decade of the nineteenth century. Moreover, the conclusion is supported by one of the most easily verified indexes of growing prosperity-the increase in the number and amount of small savings accounts in Russian banks. ${ }^{84}$ In 1886 the number of savings accounts stood at 306,000 , and grew steadily to $3,551,000$ by 1900 . Deposits rose from 42 million rubles to 662 million rubles. ${ }^{85}$ The magnitude of these figures suggests that something was "right" in the Russian economy for some ségment of the population.

55. Von Laue, "High Cost and the Gamble of the Witte System," p. 69.

56. Butmi, Itogi finansovago khoziaistva, pp. 52-53; and Von Laue, Sergei Witte, p. 274.

57. Osipov, "O nekotoroi zavisimosti," p. 380.

58. Butmi, Itogi finansovago khoziaistva, p. 52; and Von Laue, Sergei Witte, p. 274.

59. Butmi, Itogi finansovago khosiaistva, p. 52 .

60. See Osipov, "O nekotoroi zavisimosti," p. 379; and Butmi, Itogi finansovago khoziaistva, p. 52.

61. See Osipov, "O nekotoroi zavisimosti," p. 379, who shows a slow but gradual increase in consumption of kerosene from 1888 to 1894.

62. Ministerstvo Finansov, Russia, Its Industries and Trade (Glasgow: Hay, Nisbet and Co., 1901), p. 212; and Russian Journal of Financial Statistics (St. Petersburg, 1899), pp. 30-31, 62-63.

63. Russian Journal of Financial Statistics, p. 31 ; and Khromov, Ekonomicheskoe razvitic Rossii, pp. 498 and 502.

64. Crisp, "Russian Financial Policy," p. 165.

65. Khromov, Ekonomicheskoe rasvitie Rossii, p. 540. 
Both Witte's opponents and modern scholars apparently have refused to think through the implications of this evidence. Von Laue, Liashchenko, and Khromov, for example, have stated that consumption levels were improving, but they have not seen this as invalidating the crisis hypothesis. ${ }^{86}$ Modern scholars have tended to set the evidence aside, claiming that it is explained by increased consumption by the urban sector and the wealthy peasantry. ${ }^{67}$ They agree that there was greater consumption, but not on the part of the average peasant-which again raises the question of income distribution. The bias of scholars dealing with this period is illustrated in a curious passage from Von Laue. In response to Witte's claim that increased tax revenue was predicated on higher consumption levels, Von Laue states: "While Witte continued to argue that they [indirect taxes] were paid only by those who could afford them, his critics showed convincingly that many taxed items constituted part of the peasants' household economy, such as tea, vodka, matches, and kerosene." statement says that peasants purchased the items from which indirect tax receipts were derived, and thus the increased yield of tax receipts and the increase in consumption clearly means that the Russian peasantry was enjoying an improved standard of living.

There are other aspects of the peasant standard of living or index of real income which have been presented to support the contention that a crisis existed in Russian agriculture at the end of the nineteenth century. The question of the amount of food available for per capita consumption is an example. Was there more grain available per capita in Russia by 1900 than had been available in 1860 ? This is a controversial issue among scholars of Russia's economic history in the last half of the nineteenth century. Such noted authorities as Peter Liashchenko and Alexander Gerschenkron hold opposing viewpoints. Liashchenko is quite positive in his answer, arguing that for the country as a whole there was more grain per person in 1900 than in 1861 because agricultural production increased more rapidly than population. ${ }^{69}$ Gerschenkron, on the other hand, states just as positively that there was less grain per capita in Russia by 1900 because output had declined since $1870 .^{70}$ In one of his latest publications, Gerschenkron argues at length that the per capita output of wheat and rye available for domestic consumption had declined between $1870-74$ and 1896-1900. He states that in a determination of the amount of grain per capita, "it is . . . important to take account of the fact that along with an increase in exports there was also a considerable increase in marketings of products to

66. Von Laue, Sergei Witte, p. 170; Von Laue, "High Cost and the Gamble of the Witte System," p. 73; Khromov, Ekonomika Rossii, p. 207; and Lyashchenko, History of the National Economy of Russia, p. 447.

67. Von Laue, "High Cost and the Gamble of the Witte System," p. 69; and Lenin, The Development of Capitalism in Russia, pp. 166-67.

68. Von Laue, "High Cost and the Gamble of the Witte System," p. 70. Emphasis added.

69. Lyashchenko, History of the National Economy of Russia, p. 453. See also A. S. Nifontov, Zernovoe proizvodstvo Rossii vo vtoroi polovine XIX veka (Moscow, 1974), p. 284.

70. Alexander Gerschenkron, "Problems and Patterns of Russian Economic Development," in The Transformation of Russian Socicty, ed. Cyril Black (Cambridge, Mass.: Harvard University Press, 1960), p. 48; and Gerschenkron, "Agrarian Policies and Industrialization," p. 778. 
the cities whose population was rapidly growing and whose bread consumption was considerably above that of the peasantry. It is then difficult to escape the conclusion that the bread consumption of the rural population in the 1890's reached a very low point even if one abstracts from the disaster [sic] of the great famine of $1891 / 2 . " 71$

Gerschenkron's argument presents a more unfavorable picture than actually existed. First, his measure of output per capita of grain refers only to wheat and rye, and does not take into consideration barley, oats, and corn, which were becoming more important in Russia. Second, while his index for per capita output of wheat and rye was lower in 1896-1900 than in 1870-74, it shows a definite rise for the period 1886-90. It is possible to conclude from Gerschenkron's own evidence that the rural sector was experiencing a recovery and not a deepening crisis.

Goldsmith states that the volume of total agricultural output increased at a rate slightly greater than the population increase, which contradicts the picture drawn by Gerschenkron. In addition, the increase was most rapid in cereal production, and the overall agricultural "rate of growth accelerated considerably beginning with the mid-1880's after remaining low in the first two decades following the agricultural reform."72 Nevertheless, Goldsmith concludes his study of Russia's economic growth by doubting whether-in view of increased exports and industrial consumption-per capita consumption of agricultural products increased throughout the country. In fact, he feels that it might even have declined, and thus in the end would tend to agree with Gerschenkron's conclusion. ${ }^{73}$

My own research has established that, even if one excludes grain exported, there was more grain available for personal consumption in Russia by 1900 than in $1886 . .^{74}$ The Soviet scholar A. S. Nifontov has also made calculations which agree with these findings: after subtracting exports there was more grain available per capita in Russia in 1900 than in the 1880 s. $^{75}$ The question again is one of distribution. In view of the evidence regarding consumption of salt, sugar, matches, and so forth based on indirect taxes, one can reasonably infer that the peasantry was consuming more grain as the century came to a close. One would hardly want to argue that the peasantry taken as a whole was consuming more matches and less grain!

In the late nineteenth century the international grain market was in a general state of depression. The drop in prices on the international market and the intense competition of American farmers were reflected in the domestic grain market in Russia. The impact of the price decline on the peasantry is another possible measure of the agricultural crisis.

The contemporary literature is replete with discussions and evidence purporting to show that low prices and concomitant large harvests were disastrous

71. Gerschenkron, "Agrarian Policies and Industrialization," p. 778.

72. Goldsmith, "Economic Growth of Tsarist Russia," p. 442.

73. Ibid., p. 454. See also Nifontov, Zernovoe proizvodstvo Rossii, p. 310, whose data relating to grain available for rural consumption tends to support Goldsmith's conclusion.

74. See Simms, "Impact of the Russian Famine of 1891-92," p. 309.

75. Nifontov, Zernovoe proizvodstvo Rossii, p. 310. 
for the peasantry of Russia. ${ }^{76}$ Modern scholars have followed suit. The double pressure of heavy redemption payments in conjunction with falling prices "constituted the economic basis of the agrarian crisis, resulting in accumulating arrears in taxes and redemption payments, and reducing the peasant class to abject misery."77 The Soviet scholar Khromov also sees the decline in grain prices on both the international and domestic markets as contributing to the growth of arrears and the general ruin of peasant husbandry. ${ }^{78}$

The two-volume study by A. Chuprov and A. Posnikov, published in 1897, is the major exception to the standard interpretation of the impact of low grain prices upon the Russian economy. The study was commissioned by Witte to gather information to support his arguments concerning an improvement in the general well-being of the country. ${ }^{79}$ The two volumes center on the theme that low prices and abundant harvests were beneficial to the Russian peasant, the very opposite of the accepted viewpoint. Virtually everyone ridiculed Chuprov and Posnikov's findings, but their conclusions mesh with the other evidence and suggest that the economic crisis was a myth.

In order to understand the real significance of the relationship between the harvest and the price of grain, one must have a correct understanding of the nature of the grain market and other components of the national economy. The first major consideration is that not all the provinces of European Russia produced a surplus, or even a sufficiency, of grain. In the very good crop year of 1895 , for example, roughly 40 percent of all provinces had shortages of grain -eighteen guberniias out of fifty, or twenty-two out of forty-six, depending upon the source. ${ }^{80}$ Second, the largest part of the harvest did not enter the grain market. Statistical data for 1895 show that only 25 to 33 percent of the total harvest entered either export or domestic trade. This being true, price fluctuations did not affect the great bulk of the harvest in Russia. ${ }^{81}$ One needs to consider also the fact that wheat was the primary cash crop. Eighty-four percent of the wheat harvest was placed on the market in 1888-90, whereas only 20 percent of the rye crop was marketed. It was, therefore, the cultivators of wheat who were most affected by price-level changes, not the producers of rye. ${ }^{82}$ Third, the majority of peasants were consumers and not sellers of grain. ${ }^{83}$ It follows that large harvests and low prices constituted a

76. "Obezpechenie narodnago prodovol'stviia v sviazi s khlebnoi promyshlennosti," Russkoe bogatstvo, 1892, no. 3, p. 131; Iuzhakov, "Voprosy ekonomicheskago razvitiia v Rossii," pp. 203-4; Nikolai-on, "Apologiia vlasti deneg kak priznak vremeni," Russkoe bogatstvo, 1895, no. 1, p. 178; and Karyshev, "Letnie vpechatleniia," pp. 61-68, 52. See also Mendel, Dilemmas of Progress, p. 47, who outlines the legal populist view concerning low prices and the "fear" of a good harvest.

77. Watters, "The Peasant," pp. 154-55. See also Volin, A Century of Russian Agriculture, p. 60 .

78. Khromov, Ekonomika Rossii, pp. 206-7.

79. Theodore Von Laue, "The High Cost and the Gamble of the Witte System: A Chapter in the Industrialization of Russia," Journal of Economic History, 13 (1953) : 431.

80. Chuprov and Posnikov, Vliianie urozhaev i khlebnykh tsen, pp. ii-iii. For a more complete discussion, see Simms, "Impact of the Russian Famine of 1891-92," pp. $311 \mathrm{ff}$.

81. Chuprov and Posnikov, Vliianie urozhaevi khlebnykh tsen, pp. iv-v.

82. Ibid., p. vi.

83. Ibid., p. viii. See also Robinson, Rural Russia under the Old Regime, pp. 102-3; 
boon rather than a tragedy to most Russians, ${ }^{84}$ for, as Chuprov and Posnikov pointed out, the urban population, as well as the rural sector, gained from an abundant harvest with favorable prices. High yields and low prices, for example, seemed to have had a direct connection to a lower death rate and to an increase in the number of marriages. Per day labor rates also improved in good crop years. Perhaps the most important evidence that good crops and low prices were a benefit to Russia on a net basis is the fact that villagers did not strive as diligently for supplemental work in the cities in good years as during poor harvest years. ${ }^{85}$

According to the report of the minister of finance on the state budget of incomes and expenses for the year 1895:

The drop in prices for the products of the land represents an outstanding feature of the economic history of cultural states for the past quarter century. . . 86

The distinguishing characteristics of our national economy and daily life as compared with the Western European countries is incidentally involved in the supremacy of our system of natural economy both in the predominance of numbers, as well as in the total area of land owned by that same peasant population which cannot alienate the grain they produce for the market, but are themselves its consumers. That amount of agricultural products which enters into international trade and into the internal market constitutes a comparatively smail part of the total agricultural income of the country. The majority of the peasant farms obtain their monetary means not as much by the sale of grain, as by various forms of handicraft occupations, side earnings, sale of other farm products, etc.-and the numbers of peasant farms buying grain exceeds in the average years the numbers that sell it. A large crop increases the natural stores in the country which serve as the source of both personal consumption as well as for the support and improvement of agricultural production itself, provides one part of the population a greater amount of products for sale, and for the other lightens the burden of expense on the purchase of bread. In the years of good crops the peasant economy accumulates forces, increases consumption and, incidentally, improves its farming and domestic circumstances, thanks to increasing earnings from private landowners. In the years of abundant crops, the factory-plant products designed for wide consumption, as well as handicraft enterprises, widen the trade turnover, increase the profits of the transport enterprises, and raise the state incomes. For Russia, in the aggregate of her village interests and the interests of the national economy, a large crop is a blessing, even if it is accompanied by some drop in the prices of grain. . . . ${ }^{87}$

and James Mavor, An Economic History of Russia, vol. 2 (New York: Russell and Russell, 1965), p. 290.

84. See Shcherbina, "Krest'ianskie biudzhety," pp. 54-79.

85. Chuprov and Posnikov, Vliianie urozhaev $i$ khlebnykh tsen, pp. xlvii-lii, liv.

86. Ibid., p. lvi.

87. Ibid., pp. lvii-lviii. 
Thus, in terms of the peasant economy and the peasant budget, the following conclusion was drawn: "For the majority of the peasant economies, large crops bring [aggregate] well-being, even when they are accompanied by low grain prices." 88 Although the Chuprov and Posnikov findings appear to be a reasonable deduction from the evidence presented therein, the study provoked a storm of protest. As Von Laue states, "practically all economists ridiculed its conclusions." ${ }^{89}$ This, of course, excludes the thirteen economists who published articles in the work. The study was based on evidence taken largely from the 1880s, but evidence based upon the good harvests for 1893-94 also was included to back up the controversial conclusion:

According to the comments of many correspondents of the Ministry of Agriculture in the annual review of $1894, \ldots$ the peasants in this year have "spruced up," "have stocked up provisions and feed ; many will have stores to last them two or three years; obligations are being discharged, and taxes are paid regularly; the inventory is being filled in [substantiated by Goldsmith's work] ; the cattle are in good condition; there is a noticeable improvement in food and dress; the earnings have increased due to more intense work in harvesting and transporting of the crop on the landlord's estates. . . ."

"The bread the peasants eat is pure and in abundance," conveyed a correspondent of the Korochansk District; "former black, decaying roofs are being replaced with new ones; the backyards fallen into disrepair are being renovated . . . the people have cheered up, the peasant food is considerably better; meat began to appear oftener. . . . the peasants from the Kazan' province have poured their grain into the communal stores; many thousands of families have spruced up and caught their breath; part of the indebtedness has been paid, etc." Similar information was conveyed in 1894 from Olonets, Viatka, Perm, Kaluga, and from the northwestern regions. ${ }^{90}$

Zemstvo publications for 1894 and 1895 show a similar improvement in the rural sector. In Orlov province, the number of new peasant huts had increased and the peasants had added to the number of their cattle. The number of livestock was increasing in Voronezh also. In Poltava, conditions were better than they had been in years because of low grain prices and high wages for labor. As a result, very few workers had left seeking employment elsewhere. ${ }^{91}$

The discussion of the general influence of the price of grain and the yield of the harvest leads quite naturally to a specific examination of the structure of the peasant budget. The following discussion is based on Chuprov and Posnikov's study, which includes a lengthy chapter dealing with peasant budgets written by Professor F. A. Shcherbina. Conclusions in the study were drawn largely from the budgets of 230 "typical" farms and a general examination of

88. Ibid., p. xx. See also Shcherbina, "Krest'ianskie biudzhety," pp. 54-79.

89. Von Laue, "The High Cost and the Gamble of the Witte System: A Chapter in the Industrialization of Russia," p. 431.

90. Chuprov and Posnikov, Vliianie uroshaev $i$ khlebuykh tsen, p. xxi. This material is quoted at length because it stands in stark contrast to the usual picture concerning Russian rural life.

91. Ibid., p. xxii. 
the income and expenditures of 232,373 farms, as well as from data dealing with all of Russia from 1883 to 1887.92 This material is considerably more extensive than that used by Lenin in his famous work, The Development of Capitalism in Russia, which was based essentially on only 66 budgets. ${ }^{93}$

In her chapter on the influence of prices and crops upon peasant budgets, Professor Shcherbina established the fact that grain farming was the fundamental variable of peasant agriculture and the peasant economy in every region of Russia. All other aspects of agriculture, such as truck gardening and beekeeping, were in essence supplemental. ${ }^{94}$ This is why the fluctuations in grain yields and prices were so important to the peasant, both for those who were selling grain and the majority of peasants who were net purchasers of grain.

Shcherbina's very complicated but excellent analysis shows that high prices and low harvests produced a deficit to the average peasant family budget. On the other hand, low prices and abundant harvests led to a surplus in the budget. A budget surplus only occurred when the harvest increased over the previous year. After demonstrating that the model was sound theoretically, Shcherbina then programed the harvest and prices of 1891 and demonstrated that the theory stood the test of reality. ${ }^{95} \mathrm{~A}$ large harvest and low prices benefited the average budget because the peasant, after taking care of his own food needs in terms of grain, had more money to spend on other things.96 "In good crop years, the Russian peasant not only sold more grain but ate more, fed more to livestock, and built up reserves. Russian peasant agriculture, unlike that of the West, suffered not from overproduction, but from underproduction. . . ."97

The low prices and large harvests also had a very favorable impact on peasants who earned income outside of grain husbandry. In many cases, the peasants' money income came principally from "craft" earnings and not from the sale of grain. Craft earnings were used primarily for state and zemstvo taxes, rents, and the purchase of grain to supplement shortages, and thus were very important. If the outside earnings decreased, the peasant was forced to sell more of the farm products normally used to fulfill his own needs. Craft earnings, which were usually drawn from local agricultural earnings, local handicraft industries, and seasonal work, were dependent on the fluctuations of crops and prices. ${ }^{98}$ Grain prices and the harvest determined how much the farmercraftsman had to spend on the purchase of food and regulated the demand for his products. Chuprov and Posnikov demonstrated that good crops brought a rise in the handicraft industry and low crops brought a reduction. Thus the handicraft industry was depressed by the crop failure of 1891, but recovered nicely in the boom years of 1893 and $1894 .{ }^{90}$

92. Ibid., pp. $x-x$ iii.

93. Lenin, The Development of Capitalism in Russia, pp. $148 \mathrm{ff}$.

94. Shcherbina, "Krest'ianskie biudzhety," pp. 54-55.

95. Ibid., pp. 54-79. On page 75, the author acknowledges that she is holding all other variables constant.

96. Ibid., pp. 60, 74, 76. See also Osipov, "O nekotoroi zavisimosti," p. 372. The budgets were based on average expenditures and incomes of budgets throughout Russia for the period 1883-87.

97. Volin, A Century of Russian Agriculture, p. 61.

98. Chuprov and Posnikov, Vliianie urozhaev $i$ khlebnykh tsen, p. xiv.

99. Ibid., pp. xvi-xvii. 
Seasonal labor from the rural sector was also affected by the harvest and the price of grain, in that the exodus from the village to urban centers was much less when the harvest was large and grain prices were low. ${ }^{100}$ The data show that good crops and low grain prices resulted in high wages at harvest time in the chernozem region. When crops were better than average, this increase in pay was 18 percent throughout the entire black earth zone. ${ }^{101}$

Another salient point in support of the proposition that there was no agrarian crisis for the majority of peasants is the fact that real income in terms of wages began to increase in the late nineteenth century. Robinson argued that millions of peasants were either engaged in the handicraft industry of agriculture or industrial wage labor. Wage labor, which is the main concern here, was an important source of income for a huge number of peasants. While Robinson emphasized the low level of these wages, he pointed out that payments for labor began to rise in the early nineties. From 1895 into the twentieth century, there was an increase in the amount of wages paid throughout all of European Russia. In fact, wages increased faster than expenses in ten of the thirteen regions of Russia. ${ }^{102}$ This is additional evidence-though it was not Robinson's intention-which suggests improvement rather than deterioration in agricultural conditions.

Despite the weight of the evidence presented above, the crisis hypothesis might still be defended in one respect. It would have been possible for the Russian agricultural sector to become pecuniarized, and thus for the peasant to spend more money, even though total real income of the peasant was falling relative to previous years. That is, two processes might have been going on: a shift from an in kind (consumption of own products) to a money economy and a simultaneous decline in real income. This possibility was the basic point made by Lenin in The Development of Capitalism in Russia. According to Lenin, the market was being created through the pecuniarization of the peasantry, and at the same time a poverty-stricken rural proletariat was emerging. He states: "they [the rural proletariat] become poorer, but at the same time receive and spend more money-and both these sides of the process are necessary for capitalism."103

The data necessary for resolving the problem posed by Lenin apparently do not exist. Again, one must cite G. T. Robinson, who stated that income distribution data for the Russian peasantry over time which would demonstrate changes in real income are not available, or at least have not been uncovered to date. ${ }^{104}$ Even Lenin could only speculate about the economic well-being of the Russian peasantry during the last two decades of the nineteenth century.

Something might be learned, however, from data concerning wages paid to those peasants who supplemented their income by seeking employment outside their allotments. Robinson provides evidence which shows that wages paid to the peasant worker rose faster than the price of rye-his principal food-

100. Ibid., pp. xvii-xviii.

101. Ibid., pp. $x v-x v i$.

102. Robinson, Rural Russia under the Old Regime, pp. 105-6.

103. Lenin, The Development of Capitalism in Russia, p. 167.

104. Robinson, Rural Russia under the Old Regime, p. 110. 
in the 1890 s and thus constituted an increase in real income. This is a very important measure of peasant well-being in the 1890 s because "wage work in agriculture and other rural non-industrial occupations was . . . an important source of peasant income."105 In Lenin's study of peasant budgets, 30 of the 66 budgets examined had supplemental income from farm and day laboring. ${ }^{106}$ Chuprov and Posnikov's study also indicates that a large proportion of the peasantry supplemented its income via the sale of labor in some form. On the average, 30 percent of the total income of the peasant household was obtained outside of agriculture per se. ${ }^{107}$ Thus, because the largest single item of expenditure in the peasant's budget was for food, according to Lenin's data, 56 percent of the budget of the poorest families and 45 percent of the budget of the middle-income level peasants was used for food-a rise in wages relative to food prices benefited those selling their labor and constituted a gain in real income at least in terms of this very significant item in the peasant budget. ${ }^{108}$

The pecuniarization of the peasant economy in Russia does not seem to have lowered living standards. On the contrary, it seems very likely that conditions actually were improving in the last years of the nineteenth century for a majority of the Russian peasants. Given the fact that consumption of cotton, tea, sugar, matches, kerosene, tobacco, and so forth was growing absolutely, it is hardly likely that the overall standard of living of the peasant was dropping. Would there be a decline in the consumption of food, especially with food prices falling relative to other commodities, while there was a rise in the use of tea or kerosene? Assuming that the peasant acted rationally in making his economic decisions, would the peasant reduce his consumption of an absolute necessityfood-relative to consumption of cotton or matches? If the peasant's total income-monetary and in kind-was lower in the 1890 s relative to the $1880 \mathrm{~s}$, then one must accept the proposition that the peasant was willing to maintain not only current levels but to increase levels of consumption in items such as cotton and matches at the expense of his expenditure on food, his home, his land, and his livestock.

One must conclude that Russia did not experience an economic downturn in agriculture in the last years of the nineteenth century-especially after the famine of 1891-92. The vast majority of the people, the peasantry at large, was not enduring an unending spiral of decline to ruin and destitution. Virtually every index that has been used to prove the existence of the crisis-(1) tax arrears, considered by Robinson the best index of the crisis; (2) the so-called burden of indirect taxation; (3) declining output of cereal per capita; and (4) the impact of low grain prices, which was supposedly a major component of rural depression in the $1890 \mathrm{~s}$ - has been shown to have an alternative inter-

105. Ibid., p. 105.

106. Lenin, The Development of Capitalism in Russia, p. 154. In 1893, Lenin argued that the majority of the peasants met their total needs by selling their labor (Lenin, "On the So-called Market Question," p. 123).

107. Chuprov and Posnikov, Vliianie urozhaev $i$ khlebnykh tsen, pp. xii and xiv. See also Shcherbina, "Krest'ianskie biudzhety," p. 55.

108. Lenin, The Development of Capitalism in Russia, p. 151. 
pretation, one which helps instead to establish the proposition that conditions within Russia were on the upswing.

The refutation of the crisis hypothesis is based largely on a reevaluation of the "burden" of the Russian tax system, which supposedly was ruining peasant agriculture by forcing the peasant to exhaust the soil and himself in order to export grain. We know that indirect tax receipts, derived from the sale of mass consumer items such as sugar, tea, and matches, rose sharply in the last two decades of the century. It also seems clear that per capita consumption of these items was increasing. We know that scholars are in agreement that the peasant at large bore the burden of these indirect taxes. If that is the case, then the Russian peasant must obviously have been experiencing an upturn in his standard of living toward the end of the century. If he paid the sales taxes, then he must have been doing the consuming. If proponents of the crisis theory drop their contention that the mass of the peasants bore the brunt of the tax burden, then the entire premise for the theory of the Russian state exploiting the peasant by forcing him to export grain is no longer valid. ${ }^{109}$ Either way, the generally accepted theory of the deterioration and crisis within Russian agriculture has been seriously and irreparably damaged.

This interpretation does not preclude the existence of destitution and poverty within the agrarian sector of Russia. There was ample evidence--undernourished people, bad housing, serious crop failures, disease, and dearth-to demonstrate the existence of poverty. It does, however, shift the emphasis from a vast majority to a minority of the peasantry who were experiencing economic deterioration in particular areas within the central black earth provinces. The perspective is not of agriculture in a state of stagnation or decay. The evidence supporting this new interpretation now shifts the burden of proof to the advocates of the crisis hypothesis.

109. See Von Laue, "High Cost and the Gamble of the Witte System," p. 63. 